\title{
Caffeic Acid Esters Are Effective Bactericidal Compounds Against Paenibacillus larvae by Altering Intracellular Oxidant and Antioxidant Levels
}

\author{
William Collins $^{1, *}$, Noah Lowen ${ }^{2}$ and David J. Blake ${ }^{2}$ \\ 1 Department of Biochemistry and Chemistry, Fort Lewis College, 1000 Rim Dr., Durango, CO 81301, USA \\ 2 Department of Biology, Fort Lewis College, 1000 Rim Dr., Durango, CO 81301, USA \\ * Correspondence: Collins_w@fortlewis.edu; Tel.: +01-970-247-7133
}

Received: 3 June 2019; Accepted: 25 July 2019; Published: 27 July 2019

\begin{abstract}
American Foulbrood (AFB) is a deadly bacterial disease affecting pupal and larval honey bees. AFB is caused by the endospore-forming bacterium Paenibacillus larvae (PL). Propolis, which contains a variety of organic compounds, is a product of bee foraging and is a resinous substance derived from botanical substances found primarily in trees. Several compounds from the class of caffeic acid esters, which are commonly found in propolis, have been shown to have antibacterial activity against PL. In this study, six different caffeic acid esters were synthesized, purified, spectroscopically analyzed, and tested for their activity against PL to determine the minimum inhibitory concentrations (MICs) and minimum bactericidal concentrations (MBCs). Caffeic acid isopropenyl ester (CAIE), caffeic acid benzyl ester (CABE), and caffeic acid phenethyl ester (CAPE) were the most effective in inhibiting PL growth and killing PL cell with MICs and MBCs of $125 \mu \mathrm{g} / \mathrm{mL}$ when used individually, and a MIC and MBC of $31.25 \mu \mathrm{g} / \mathrm{mL}$ for each compound alone when CAIE, CABE, and CAPE are used in combination against PL. These compounds inhibited bacterial growth through a bactericidal effect, which revealed cell killing but no lysis of PL cells after $18 \mathrm{~h}$. Incubation with CAIE, CABE, and CAPE at their MICs significantly increased reactive oxygen species levels and significantly changed glutathione levels within PL cells. Caffeic acid esters are potent bactericidal compounds against PL and eliminate bacterial growth through an oxidative stress mechanism.
\end{abstract}

Keywords: Apis millifera; Paenibacillus larvae; propolis; caffeic acid esters; minimum inhibitory concentration (MIC)

\section{Introduction}

USA and European beekeepers face high honey bee (Apis millifera) colony losses each year. Indeed, the BeeInformed Partnership Survey, a national epidemiological analysis of honey bee health, indicated that $40.1 \%$ of all USA colonies were lost in 2018 [1]. There are many factors involved in these losses and it is now generally accepted that no single issue is completely responsible for the colony mortality increases observed over the last 10 years [2]. However, viruses, bacteria, fungi, and parasites that commonly harm honey bees combined with the chemical inputs routinely utilized to ameliorate these afflictions are now understood to be a major cause of the decline of honey bee health worldwide $[3,4]$.

One of the most dangerous pathogens that can infect honey bee colonies is the endospore-forming bacterium Paenibacillus larvae (PL) [5]. This extremely contagious bacterium, known commonly in the beekeeping community as American foulbrood (AFB), adversely affects honey bees during the larval or pupal stages $[5,6]$. The endospore, once inside a colony, is typically distributed to larvae during routine feeding by nurse bees, and after ingestion of the spores ultimately results in septicemia of the larvae [7]. The ensuing corpses then release PL spores, which are concomitantly dispersed throughout the brood 
nest $[6,8,9]$. Colony mortality is commonly observed within one season after infection, and infected colonies can then horizontally transmit PL spores to other colonies [10].

While a colony suffering from AFB can be identified by conspicuous symptoms such as irregular brood cappings, dark and punctured caps emitting foul odors, and brown residues of dead larvae [11], few treatment options exist to effectively fight the infection. Currently, broad spectrum antibiotics such as sulfathiazole, tylosin tartrate/Tylan, and oxytetracycline hydrochloride (OTC) are used to inhibit the growth of PL. However, the extreme dependence on these therapies and their subsequent overuses has led to the appearance of resistant strains [12]. As a result, the use of antibiotics to treat AFB in many countries (including all of the EU members) is now illegal, and as a direct consequence, colonies infected with PL in these countries must be destroyed through burning to prevent further spread of the disease [13]. Compounding this issue, as of 2017, the Food and Drug Administration now requires beekeepers within the USA to get a prescription from a veterinarian each time they use antibiotics within a honey bee colony to combat AFB [14].

Understandably, honey bees already possess a variety of social immune responses that attempt to mitigate colony-level infections such as AFB [15-17]. The hot, humid, and densely packed interior of a bee colony is an ideal environment for the propagation of many pathogens [18]. Therefore, to prevent unwanted pathogenic growth inside colonies, bees actively gather phytochemical-rich plant resins (termed propolis when mixed with wax) and deposit them throughout the structure of the colony [19-21]. The phytochemical composition of these resins is a complex mixture of biologically active terpenes, terpenoids, and phenols, with as many as 300 different molecules found within each resin sample [22-24]. Importantly, recent research has shown some propolis extracts to have biological activity against PL [25].

Unfortunately, because the chemical composition of propolis varies by location, season, and botanical availability it is difficult to standardize the antimicrobial efficacy of propolis extracts across multiple studies [26-28]. Additionally, the chemical variability of propolis (and thus efficacy) also creates considerable challenges in the development of quality-controlled therapies [29,30]. To directly address this issue, our laboratories have begun a program in the systematic synthesis and testing of individual natural product components of propolis against PL. We have begun our investigations with the caffeic ester family of molecules. Members of this class of molecules have already been shown to have considerable biological activity against many different Gram-positive bacteria and are also commonly identified in North American and European propolis samples found near poplar resin sources [22,31,32]. Moreover, extracts of mixtures of caffeic esters have been shown to inhibit PL growth [33]. The aim of this work is to show that, using compounds inexpensively prepared in a laboratory on a gram scale, we are able to not only determine potential highly effective compounds for critically needed AFB therapies, but also a putative mechanism of antibiotic action for this class of molecules.

\section{Materials and Methods}

\subsection{General Materials for Synthetic Procedures}

Reagents and solvents were purchased from commercial sources and used without further purification unless otherwise specified. Reaction solvents, and solvents for liquid phase extraction were: ethyl acetate (Fisher Scientific, Suwanee, GA, USA, ACS grade,), hexanes (Acros, Trenton, NJ, USA, ACS grade), dichloromethane (Fisher Scientific, ACS grade), methanol (Acros, ACS grade), ethanol (Acros, ACS grade), dimethylformamide (Aldrich, Raleigh, NC, USA, ACS grade), and toluene (Acros, ACS grade). Reagents used were: oxalyl chloride (CAS: 79-37-8, Sigma, Allentown, PA, USA, ACS grade), pyridine (CAS: 110-86-1, Aldrich, ACS grade), benzylalcohol (CAS: 100-51-6, Aldrich, reagent plus grade), cinnamyl alcohol (CAS: 104-54-1, Aldrich), phenethylalcohol (CAS: 60-12-8, Aldrich), 3-methyl-2-butenyl alcohol (CAS: 556-82-1, Aldrich), magnesium sulfate (CAS: 7487-88-9, Aldrich), potassium carbonate (CAS: 584-08-7, Aldrich), caffeic acid (CAS: 331-39-5, Aldrich), 
and ferulic acid (CAS: 1135-24-6, Aldrich). TLC/chromatography solvents used were: hexanes (CAS: 110-54-3, Fisher Scientific, ACS grade), and ethyl acetate (CAS: 141-78-6, Fisher Scientific, ACS grade). Diacetylcaffeic acid was prepared from caffeine acid in near quantitative yield (98\%) and on a gram scale by following a known protocol (LeBlanc et al. 2012). ${ }^{1} \mathrm{H}$ and ${ }^{13} \mathrm{C}$ NMR was recorded on JEOL (400 MHz ${ }^{1} \mathrm{H}$ spectrometer and $125 \mathrm{MHz}{ }^{13} \mathrm{C}$ spectrometer) in deuterochloroform (CAS: 865-49-6, Aldrich, ACS grade) or DMSO-d 6 (CAS: 2206-27-1, Aldrich, ACS grade). Spectra were referenced to residual chloroform $\left(7.26 \mathrm{ppm},{ }^{1} \mathrm{H}\right)$. Chemical shifts are reported in ppm, multiplicities are indicated by s (singlet), d (doublet), t (triplet), q (quartet), p (pentet), h (hextet), m (multiplet), and br (broad). Coupling constants, J, are reported in Hertz. Infrared spectra (IR) were recorded on a Thermo Fisher Scientific Nicolet iS10 spectrophotometer. Peaks are recorded in $\mathrm{cm}^{-1}$ with indicated relative intensities: s (strong, 67-100\%); m (medium, 34-66\%); and w (weak, 0-33\%). Analytical thin-layer chromatography was performed on Merck (Kenilworth, NJ, USA) silica gel 60 plates with F-254 indicator. Visualization was accomplished by ultraviolet (UV) light. Silica gel used for column chromatography was obtained from SiliCycle. All yields refer to spectroscopically $\left({ }^{1} \mathrm{H}-\mathrm{NMR}\right)$ homogeneous material.

\subsection{Preparation of Caffeic Ester Derivatives}

General procedure for esterification: Diacetylcaffeic acid (580 mg, $2.195 \mathrm{mmol}, 1$ eq.) was dissolved in $\mathrm{CH}_{2} \mathrm{Cl}_{2}(12 \mathrm{~mL}, 188 \mathrm{mmol})$ and placed under a nitrogen atmosphere. Oxalyl chloride $(0.38 \mathrm{~mL}$, $4.39 \mathrm{mmol}, 2$ eq.) was added dropwise to this solution before adding DMF (5 drops). The reaction mixture was stirred for $16 \mathrm{~h}$ at room temperature. Excess oxalyl chloride was removed under reduced pressure via rotovap, and the resulting oil was dissolved in toluene $(25 \mathrm{~mL})$. Pyridine $(2 \mathrm{~mL})$ was added dropwise to this solution before adding the alcohol undergoing the esterification reaction $(4.4 \mathrm{mmol}$, 2 eq.). This solution was stirred at room temperature for $3 \mathrm{~h}$. The solvent was then removed via rotovap, and the resulting oil was dissolved in EtOAc $(50 \mathrm{~mL})$ before being transferred to a separatory funnel. The aqueous layer was removed, and the organic layer was washed with deionized water $(2 \times 50 \mathrm{~mL})$ followed by brine $(2 \times 50 \mathrm{~mL})$. The organic layer was dried over $\mathrm{MgSO}_{4}$, filtered, and concentrated on a rotovap. The crude residue was purified by column chromatography (silica gel, EtOAc/hexanes gradient: $20 / 80$ to $80 / 20)$.

\subsubsection{Caffeic Acid Cinnamyl Ester Diacetate}

White solid (73\%). IR (ATR) cm $\mathrm{cm}^{-1}$ : 1762 (s), 1704 (s), 1635 (w), 1506 (w), 1369 (w), 1317 (w), 1256 $(\mathrm{m}) ;{ }^{1} \mathrm{H}$ NMR $\left(\mathrm{CDCl}_{3}\right)$ 7.19-7.43 (m, 5H), $7.65(\mathrm{~d}, \mathrm{~J}=16.5 \mathrm{~Hz}, 1 \mathrm{H}), 7.40(\mathrm{~d}, \mathrm{~J}=7.3 \mathrm{~Hz}, 1 \mathrm{H}), 7.35(\mathrm{~d}$, $\mathrm{J}=1.4 \mathrm{~Hz}, 1 \mathrm{H}), 7.32(\mathrm{~d}, \mathrm{~J}=7.3 \mathrm{~Hz}, 1 \mathrm{H}), 6.68(\mathrm{~d}, \mathrm{~J}=16.0 \mathrm{~Hz}, 1 \mathrm{H}), 6.41(\mathrm{~d}, \mathrm{~J}=16.0 \mathrm{~Hz}, 1 \mathrm{H}), 6.32(\mathrm{dt}$, $\mathrm{J}=16.0,6.9 \mathrm{~Hz}, 1 \mathrm{H}), 4.85(\mathrm{t}, \mathrm{J}=6.9 \mathrm{~Hz}, 1 \mathrm{H}), 2.3(\mathrm{apd}, 6 \mathrm{H}) ;{ }^{13} \mathrm{C} \mathrm{NMR}\left(\mathrm{CDCl}_{3}\right)$ 168.3, 168.1, 165.6, 143.9, $143.5,142.9,136.2,135.4,133.3,128.9,128.5,126.9,126.7,124.1,123.1,122.9,65.2,20.5,20.5$.

\subsubsection{Caffeic Acid Benzyl Ester Diacetate}

White solid (75\%). IR (ATR) $\mathrm{cm}^{-1}: 3347(\mathrm{w}), 3308(\mathrm{w}), 1687(\mathrm{~m}), 1598(\mathrm{~m}), 1535(\mathrm{w}), 1444(\mathrm{w}), 1364$ (w), $1278(\mathrm{~m}), 1172(\mathrm{~m}) ;{ }^{1} \mathrm{H}$ NMR $\left(\mathrm{CDCl}_{3}\right) 7.67-7.63(\mathrm{~d}, \mathrm{~J}=16.0 \mathrm{~Hz}, 1 \mathrm{H}), 7.39(\mathrm{~s}, 1 \mathrm{H}), 7.38(\mathrm{~d}, \mathrm{~J}=11.9 \mathrm{~Hz}$, $1 \mathrm{H}), 7.22-7.19(\mathrm{~d}, \mathrm{~J}=8.2 \mathrm{~Hz}, 1 \mathrm{H}), 6.44(\mathrm{~d}, \mathrm{~J}=16.0 \mathrm{~Hz}, 1 \mathrm{H}), 5.23(\mathrm{~s}, 1 \mathrm{H}), 2.29-2.28(\mathrm{apd}, 6 \mathrm{H}) ;{ }^{13} \mathrm{C} \mathrm{NMR}$ $\left(\mathrm{CDCl}_{3}\right)$ 168.1, 168.0, 166.4, 143.6, 143.3, 142.5, 135.9, 133.3, 128.7, 128.3, 126.4, 124.0, 122.8, 119.1, 66, 20.7, 20.0.

\subsubsection{Caffeic Acid Phenethyl Ester Diacetate}

White solid (89\%). IR (ATR) cm $\mathrm{cm}^{-1}: 3381(\mathrm{w}), 3329(\mathrm{w}), 3066(\mathrm{w}), 3030(\mathrm{w}), 2942(\mathrm{w}), 2895(\mathrm{w}), 2870$ (w), 1766 (s), 1697 (s), 1636 (s), $1584(\mathrm{w}), 1507$ (s), 1455 (w), 1420 (s), 1369 (s), 1321 (s), 1276 (s), 897 (s); ${ }^{1} \mathrm{H} \mathrm{NMR}\left(\mathrm{CDCl}_{3}\right) 7.6(\mathrm{~d}, \mathrm{~J}=16.0,1 \mathrm{H}), 7.4(\mathrm{~d}, \mathrm{~J}=1.8,1 \mathrm{H}), 6.4(\mathrm{~d}, \mathrm{~J}=16.0,1 \mathrm{H}), 4.4(\mathrm{t}, \mathrm{J}=2.1,2 \mathrm{H}), 3.0(\mathrm{t}$, $\mathrm{J}=2.1,2 \mathrm{H}), 2.3(\mathrm{~d}, \mathrm{~J}=3.7,6 \mathrm{H}) ;{ }^{13} \mathrm{C} \mathrm{NMR}\left(\mathrm{CDCl}_{3}\right)$ 168.2, 168.1, 166.6, 143.6, 143.0, 142.5, 137.9, 133.4, $129.0,128.6,126.7,126.5,124.0,122.8,119.3,65.3,35.3,20.8$. 


\subsubsection{Caffeic Acid Isopropenyl Ester Diacetate}

White solid (41\%). IR (ATR) cm $\mathrm{cm}^{-1}: 3380(\mathrm{w}), 3331$ (w), $2940(\mathrm{w}), 2895(\mathrm{w}), 1760(\mathrm{w}), 1699(\mathrm{~s}), 1507$ (s), 1450 (w), 1420 (s), 1276 (s); ${ }^{1} \mathrm{H} \mathrm{NMR}\left(\mathrm{CDCl}_{3}\right)$ 7.62-7.58 (d, J = $\left.16.0 \mathrm{~Hz}, 1 \mathrm{H}\right), 7.39-7.37$ (m, J = 8.2, $2.3 \mathrm{~Hz}, 1 \mathrm{H}), 7.33-7.33(\mathrm{~d}, \mathrm{~J}=2.3 \mathrm{~Hz}, 1 \mathrm{H}), 7.21-7.19(\mathrm{~d}, \mathrm{~J}=8.2 \mathrm{~Hz}, 1 \mathrm{H}), 6.39-6.35(\mathrm{~d}, \mathrm{~J}=16.0 \mathrm{~Hz}, 1 \mathrm{H})$, 5.42-5.38 (t, J = 8.7, 7.3 Hz, $1 \mathrm{H}), 4.70-4.68(\mathrm{~d}, \mathrm{~J}=7.3,2 \mathrm{H}), 2.29-2.29$ (d, J = 2.6 Hz, 6H) 1.77-1.74 (d, $\mathrm{J}=15.1,6 \mathrm{H}){ }^{13} \mathrm{C} \mathrm{NMR}\left(\mathrm{CDCl}_{3}\right)$ 171.0, 168.0, 166.0, 166.2, 143.7, 142.5, 139.2, 133.1, 126.3, 124.3, 122.8, $119.4,118.7,61.5,60.3,26.1,20.5,17.8,14.2$

General procedure for deprotection: To a round bottom flask was added the purified acetylated ester $(3.24 \mathrm{mmol})$ and $\mathrm{MeOH}: \mathrm{CH}_{2} \mathrm{Cl}_{2}(12 \mathrm{~mL}, 1: 1)$. To this solution was added $\mathrm{K}_{2} \mathrm{CO}_{3}(330 \mathrm{mg}$, $3.53 \mathrm{mmol}$ ) and the reaction was stirred at room temperature. The reaction was monitored for completion via TLC (1:1 EtOAc: hexanes) and, once complete, the solvent was removed under reduced pressure in a rotovap. The resulting residue was dissolved in EtOAc $(50 \mathrm{~mL})$, and the aqueous layer was removed. The organic layer was washed with water $(30 \mathrm{~mL})$ and brine $(30 \mathrm{~mL})$ before being dried over $\mathrm{MgSO}_{4}$, filtered, and concentrated via rotovap.

\subsubsection{Caffeic Acid Cinnamyl Ester (CACE)}

Brown solid (68\%). IR (ATR) $\mathrm{cm}^{-1}: 3347(\mathrm{w}), 3308(\mathrm{w}), 1687(\mathrm{~m}), 1598(\mathrm{~m}) ;{ }^{1} \mathrm{H}$ NMR (DMSO) 7.57 $(\mathrm{d}, \mathrm{J}=16.5 \mathrm{~Hz}, 1 \mathrm{H}), 7.38(\mathrm{~d}, \mathrm{~J}=7.3 \mathrm{~Hz}, 2 \mathrm{H}), 7.32-7.18(\mathrm{~m}, 3 \mathrm{H}), 7.06(\mathrm{~d}, \mathrm{~J}=0.9 \mathrm{~Hz}, 1 \mathrm{H}), 6.91(\mathrm{~d}, \mathrm{~J}=8.2$ $\mathrm{Hz}, 1 \mathrm{H}), 6.86(\mathrm{~d}, \mathrm{~J}=15.6 \mathrm{~Hz}, 1 \mathrm{H}), 6.65(\mathrm{~d}, \mathrm{~J}=0.9 \mathrm{~Hz}, 1 \mathrm{H}), 6.32(\mathrm{dt}, \mathrm{J}=15.7,6.9 \mathrm{~Hz}, 1 \mathrm{H}), 6.26(\mathrm{~d}, \mathrm{~J}=16.0$ $\mathrm{Hz}, 1 \mathrm{H}), 4.81(\mathrm{t}, \mathrm{J}=6.9 \mathrm{~Hz}, 1 \mathrm{H}) ;{ }^{13} \mathrm{C}$ NMR (DMSO) 167.2, 147.3, 145.5, 144.8, 136.5, 134.1, 128.9, 128.2, $126.9,123.8,122.1,115.6,114.9,114.3,65.1$

\subsubsection{Caffeic Acid Benzyl Ester}

Tan solid (33\%). IR (ATR) cm $\mathrm{cm}^{-1}: 3459(\mathrm{~m}), 3319(\mathrm{~m}) ; 1690(\mathrm{~m}), 1602(\mathrm{~m}) ;{ }^{1} \mathrm{H}$ NMR (DMSO) 7.25-7.21 $(\mathrm{d}, \mathrm{J}=15.6 \mathrm{~Hz}, 1 \mathrm{H}), 7.2(\mathrm{~s}, 1 \mathrm{H}), 7.01(\mathrm{~s}, 1 \mathrm{H}), 6.68(\mathrm{~s}, 1 \mathrm{H}), 6.54-6.44(\mathrm{~m}, 2 \mathrm{H}), 5.89-5.85(\mathrm{~d}, \mathrm{~J}=16.0 \mathrm{~Hz}, 1 \mathrm{H})$, $4.85(\mathrm{~s}, 1 \mathrm{H}), 3.72-3.71(\mathrm{~d}, \mathrm{~J}=6.9 \mathrm{~Hz}, 1 \mathrm{H}), 1.65(\mathrm{~s},-\mathrm{OH}), 0.89(\mathrm{~s},-\mathrm{OH}) ;{ }^{13} \mathrm{C}$ NMR (DMSO) 167.0, 148.1, $145.5,145.3,136.2,128.4,127.9,126.0,121.5,115.6,114.4,113.9,65.7$

\subsubsection{Caffeic Acid Phenethyl Ester}

Light brown solid (79\%). IR (ATR) $\mathrm{cm}^{-1}: 3065$ (w), $3031(\mathrm{w}), 2966(\mathrm{w}), 2894(\mathrm{w}), 2871(\mathrm{w}), 1767$ (s), 1697 (s), 1602 (w), 1582 (w), 1507 (s), 1454 (w), 1422 (m), 1369 (s), 1321 (m), 1276 (m), 1256 (s), 1107 (s), 989 (s), 874 (s), 701 (s); ${ }^{1} \mathrm{H}$ NMR (DMSO) 7.5 (d, J = 16.0, 1H), 7.0 (s, 1H), 6.9 (d, J = 10.8, 1H), 6.8 (d, $\mathrm{J}=7.8,1 \mathrm{H}), 6.2(\mathrm{~d}, \mathrm{~J}=15.6,1 \mathrm{H}), 4.4(\mathrm{t}, \mathrm{J}=6.9,2 \mathrm{H}), 3.0(\mathrm{t}, \mathrm{J}=6.9,2 \mathrm{H}) ;{ }^{13} \mathrm{C}$ NMR (DMSO) 167.3, 147.5, $145.3,145.0,138.0,128.9,128.4,126.7,126.5,121.8,115.5,114.6,114.3,64.7,35.2$

\subsubsection{Caffeic Acid Isopropenyl Ester}

Light brown solid (61\%). IR (ATR) cm $\mathrm{cm}^{-1}: 3060$ (w), 2961 (w), 2871 (w), 1767 (s), 1697 (s), 1605 (w), 1579 (w), 1510 (s), 1454 (w), 1422 (m), 1275 (m), 872 (s); ${ }^{1} \mathrm{H}$ NMR (DMSO) 7.56(d, J = 16.0 Hz, 1H), 7.09 $(\mathrm{s}, 1 \mathrm{H}), 6.99(\mathrm{~d}, \mathrm{~J}=8.7 \mathrm{~Hz}, 1 \mathrm{H}), 6.85(\mathrm{~d}, \mathrm{~J}=8.2 \mathrm{~Hz}, 1 \mathrm{H}), 6.25(\mathrm{~d}, \mathrm{~J}=16.0,1 \mathrm{H}), 5.4(\mathrm{t}, \mathrm{J}=6.5 \mathrm{~Hz}, 1 \mathrm{H}), 4.67$ $(\mathrm{d}, \mathrm{J}=7.3 \mathrm{~Hz}, 2 \mathrm{H}), 1.75(\mathrm{apd}, \mathrm{J}=14.7,6 \mathrm{H}) ;{ }^{13} \mathrm{C}$ NMR $(\mathrm{DMSO}) 168.5,146.7,145.6,144.0,139.7,127.3$, $122.4,118.4,115.6,115.2,114.5,61.8,25.9,18.0$

\subsection{Bacterial Strains and Growth Conditions}

Paenibacillus larvae (PL) was obtained from ATCC \#9545 (Manassas, VA, USA) and cultured in either brain-heart infusion medium supplemented with $1 \mathrm{mg} / \mathrm{L}$ thiamine (BHIT) or Mueller-Hinton broth, yeast extract, potassium phosphate, glucose, and pyruvate (MYPGP) supplemented with $1 \mathrm{mg} / \mathrm{L}$ thiamine at $37^{\circ} \mathrm{C}$ as previously described [34]. The strain was maintained in BHIT and new cultures were inoculated every 24-48 h. The day before each assay described below, an overnight agitated culture was prepared in BHIT or MYPGP liquid broth and set in a $37^{\circ} \mathrm{C}$ incubator for an overnight 
incubation. BHIT was used to culture P. larvae as suggested by the manufacture (ATCC), and MYPGP was used because is routinely used to cultivate P. larvae for AFB diagnosis and yields the highest percentage of spore recovery [34].

\subsection{Determination of Minimal Inhibitory Concentration and Minimal Bactericidal Concentration}

Stock concentrations of each compound were freshly prepared as $10.5 \mathrm{mg} / \mathrm{mL}$ solutions in dimethyl sulfoxide (DMSO). Each stock solution was used for serial dilutions in a 96-well microplate from 0 to $500 \mu \mathrm{g} / \mathrm{mL}$ (final concentration) including 250, 125, 62.5, 31.25, 15.63, 7.81, and $3.90 \mu \mathrm{g} / \mathrm{mL}$ concentrations as previously described [33]. Briefly, $10 \mu \mathrm{L}$ of an overnight bacterial suspension was added to each well containing $180 \mu \mathrm{L}$ of either BHIT or MYPGP. Bacterial growth in either BHIT or MYPGP did not affect the minimum inhibitory concentration (MIC). $10 \mu \mathrm{L}$ of the serially diluted compounds was added to each well. The microplate was incubated for $18 \mathrm{~h}$ at $37^{\circ} \mathrm{C}$. Absorbance was acquired at $600 \mathrm{~nm}$ using the Infinite M200 Microplate reader (Tecan, San Jose, CA, USA). For the negative control, $P$. larvae cells were prepared with culture media, bacteria, and the corresponding amount of DMSO only. For the positive control, $10 \mu \mathrm{L}$ of tetracycline hydrochloride (Fisher Scientific, Suwanee, GA) was added to each well at a final concentration of $20 \mu \mathrm{g} / \mathrm{mL}$. Four independent biological replicates were performed to establish the MIC using two to six technical replicates for each experiment $(n=2-6)$. For the minimum bactericidal concentrations (MBC) assay, serially diluted bacterial samples from the $18 \mathrm{~h}$ MIC experiments were plated on BHIT agar plates and incubated for an additional 18 $\mathrm{h}$ overnight at $37^{\circ} \mathrm{C}$. Colonies were enumerated and the lowest compound concentration required to achieve bactericidal killing, which was defined as a $99.9 \%$ reduction in the initial inoculum, was identified as the MBC.

\subsection{Flow Cytometry Analysis}

To determine whether the inhibitory caffeic acid derivatives were bacteriostatic or bacteriolyticat their MICs, flow cytometry was used as previously described [35]. Briefly, P. larvae were incubated overnight in BHIT with either caffeic acid isopropenyl ester (CAIE), caffeic acid benzyl ester (CABE), or caffeic acid phenethyl ester (CAPE) at $125 \mu \mathrm{g} / \mathrm{mL}$ for $18 \mathrm{~h}$ at $37^{\circ} \mathrm{C}$. After incubation, $50 \mu \mathrm{L}$ of each bacterial sample was diluted in $425 \mu \mathrm{L}$ cold, filter sterilized PBS, and kept on ice. Propidium iodide (PI) (Invitrogen, Carlsbad, CA, USA) (1 mg/mL solution) was added for $20 \mathrm{~min}$ at a final concentration of $30 \mathrm{ng} / \mathrm{mL}(44.8 \mu \mathrm{M})$. Fluorescence was quantified through a BD Accuri C6 Flow cytometer (BD, Franklin Lakes, NJ, USA) and the percent of cells that were PI positive were quantified from a sample of 10,000 events. For the negative control, P. larvae cells were prepared in BHIT media and bacteria only. For the positive control, Triton-X100 (0.001\% final concentration) was added to culture media and bacteria for $3 \mathrm{~h}$ to induce lysis. Four independent biological replicates were performed using three technical replicates for each experiment $(n=3)$.

\subsection{Quantification of Intracellular Reactive Oxygen Species and Glutathione Levels}

To determine if either CAIE, CABE, or CAPE would generate intracellular reactive oxygen species (ROS) in P. larvae, cell-permeant $2^{\prime}, 7^{\prime}$-dichlorodihydrofluorescein diacetate $\left(\mathrm{H}_{2} \mathrm{DCFDA}\right)$ was used as previously described [36]. Briefly, stock concentrations of each compound (CAIE, CABE, or CAPE) were freshly prepared as $10.5 \mathrm{mg} / \mathrm{mL}$ solution in $50 \%$ ethanol. P. larvae were incubated with $10 \mu \mathrm{M}$ $\mathrm{H}_{2}$ DCFDA for 45 min in the dark, washed with PBS, added to the microplate, and treated with either CAIE, CABE, or CAPE at $125 \mu \mathrm{g} / \mathrm{mL}$ or $3 \% \mathrm{H}_{2} \mathrm{O}_{2}$ for $18 \mathrm{~h}$ at $37^{\circ} \mathrm{C}$. Fluorescence (excitation $=485 \mathrm{~nm}$, emission $=535 \mathrm{~nm}$ ) was acquired using the Infinite M200 Microplate reader. $\mathrm{H}_{2} \mathrm{O}_{2}$ was added to the cells at a final concentration of $3 \%$ and used as a positive control. Three independent biological replicates were performed using two to six technical replicates for each experiment $(n=2-6)$. To quantify intracellular glutathione (GSH) levels, cells were exposed to either CAIE, CABE, or CAPE at their MIC for either 1.5, 3 or $6 \mathrm{~h}$. GSH levels were quantified through the GSH-Glo Glutathione assay as recommended by the manufacturer for cells grown in suspension (Promega, Madison, WI, USA). 
The number of PL cells were enumerated prior to GSH quantification and 1000 cells were used for each sample. Luminescence was acquired using the Infinite M200 Microplate reader. Luminescence values for all samples were within the GSH standard curve. One independent biological replicate was performed using three technical replicates for each experimental group $(n=3)$.

\subsection{Statistical Analysis}

Data are presented as mean \pm standard deviation (SD). Analyses were done using GraphPad Prism 6.0 (San Diego, CA). A two-way Analysis of variance (ANOVA) was used to compare among more than two experimental groups with two independent variables. A one-way ANOVA was used to compare among more than two experimental groups with one independent variable. A $t$-test was used to compare two groups with one independent variable. Significance was noted at $p<0.05$.

\section{Results}

The synthesis of the library of caffeic acid esters (Scheme 1) began with an esterification of the synthetically derived caffeic acid diacetate [37]. This was accomplished through the in-situ formation of an acyl chloride with subsequent displacement by an alcohol. The resultant protected esters could be isolated, after column chromatography, in moderate to good yields (41-89\%). Deprotection using basic methanol then afforded the pure desired products in moderate yield (33-79\%) without the need for further chromatographic purification as observed previously [38]. This simple three-step protocol, originating from commercially available material, allowed for the generation of products on a gram scale in moderate to good (29-68\%) overall yield for testing. In all cases, yields were determined by spectroscopically $\left({ }^{1} \mathrm{H}-,{ }^{13} \mathrm{C}-\mathrm{NMR}\right.$, FTIR) homogenous material that matched previously reported structural data for these compounds [39].

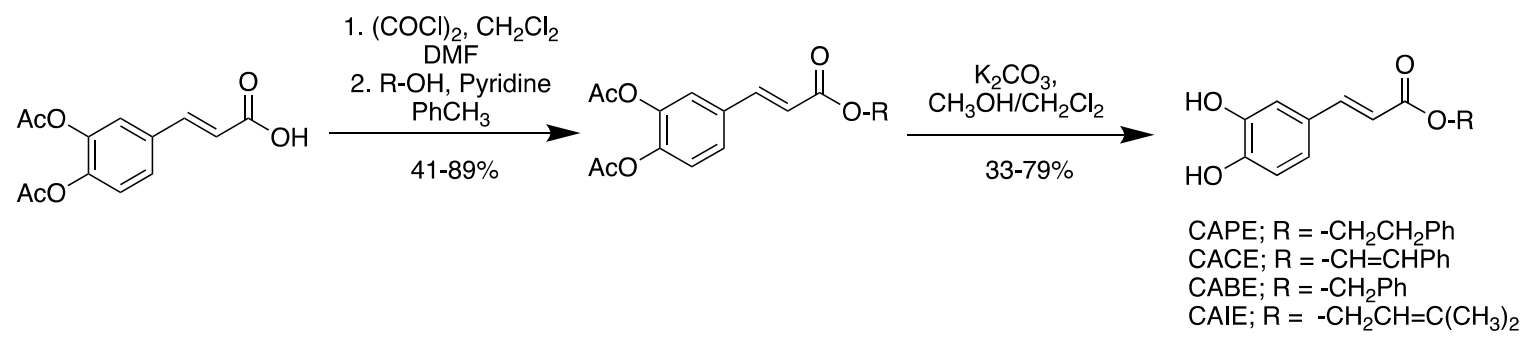

Scheme 1. Synthetic route to caffeic acid ester compound library. CAPE = caffeic acid phenethyl ester, $\mathrm{CACE}=$ caffeic acid cinnamyl ester, $\mathrm{CABE}=$ caffeic acid benzyl ester, CAIE $=$ caffeic acid isopropenyl ester, $\mathrm{DMF}=$ dimethyl formamide.

To determine the MICs of the six caffeic/ferulic acid derivatives, all stock concentrations were solubilized in DMSO and then diluted in BHIT or MYPGP. The MICs obtained were determined after $18 \mathrm{~h}$. The compounds with the lowest MICs were CAIE, CABE, or CAPE, which were $125 \mu \mathrm{g} / \mathrm{mL}$ (Table 1). Three compounds CA, FA, and CACE had MICs greater than $500 \mu \mathrm{g} / \mathrm{mL}$, which was the highest concentration used in the assay. Since CAIE, CABE, or CAPE were all inhibitory against $P$. larvae, we tested whether a lower MIC could be acquired using the three compounds in a mixture. The three compounds individually had lower MIC's of $31.25 \mu \mathrm{g} / \mathrm{mL}$ when incubated together with P. larvae (Table 1). MBCs were also determined for each effective compound and caffeic acid mixture. The MBCs were equivalent to the MICs (Table 1). 
Table 1. Minimum Inhibitory Concentration (MIC) and Minimum Bactericidal Concentration (MBC) for individual caffeic acid esters or for a combination treatment against $P$. larvae.

\begin{tabular}{ccccc}
\hline Compound Name & $\begin{array}{c}\text { Compound } \\
\text { Abbreviation }\end{array}$ & $\begin{array}{c}\text { Molecular } \\
\text { Weight }\end{array}$ & MIC $(\mu \mathrm{g} / \mathrm{mL})$ & $\begin{array}{c}\text { MBC } \\
(\mu \mathrm{g} / \mathrm{mL})\end{array}$ \\
\hline Caffeic Acid & CA & 180.16 & $>500$ & ND \\
\hline Ferulic Acid & FA & 194.19 & $>500$ & ND \\
\hline Caffeic acid cinnamyl ester & CACE & 296.32 & $>500$ & ND \\
\hline Caffeic acid isopropenyl ester & CAIE & 248.28 & 125 & 125 \\
\hline Caffeic acid phenethyl ester & CAPE & 284.31 & 125 & 125 \\
\hline Caffeic acid benzyl ester & CABE & 270.28 & 125 & 125 \\
\hline Combination of 3 compounds & CAIE, CAPE, CABE & & 31.25 & 31.25 \\
\hline
\end{tabular}

The mechanism of action of these caffeic acid derivatives are currently unknown. To identify whether these compounds acted as bacteriolytic or bacteriostatic compounds, CAIE, CABE, or CAPE were incubated with P. larvae at their MICs individually for $18 \mathrm{~h}$. Lysed cells, indicative of a bacteriolytic mechanism, were quantified through flow cytometry and identified as PI positive cells. In the negative control, approximately $7 \%$ of cells were PI positive after $18 \mathrm{~h}$, indicating the culture had reached stationary phase (Figure 1). Incubating P. larvae in TX-100 for three hours significantly increased the percent PI positive cells to $23 \%$ of the total cells enumerated. Incubation with either CAIE, CABE, or CAPE led to a significant reduction in the percent of PI positive cells to less than one percent in all cultures tested, indicating these compounds inhibited bacterial growth without leading to cell lysis.

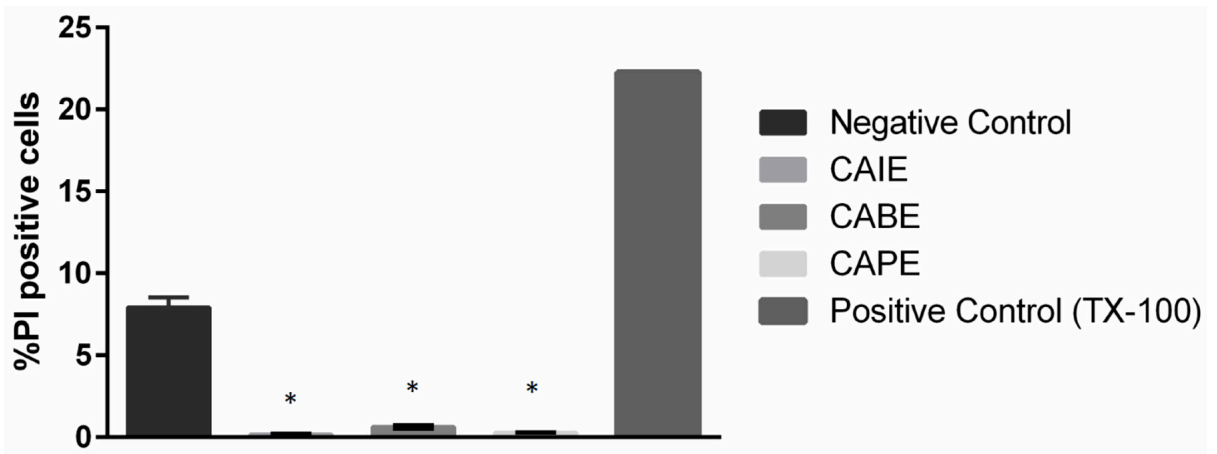

Figure 1. Bacteriostatic effect of the novel inhibitory compounds on Paenibacillus larvae. Cells were incubated in brain-heart infusion medium supplemented with $1 \mathrm{mg} / \mathrm{L}$ thiamine (BHIT) at $37^{\circ} \mathrm{C}$ for $18 \mathrm{~h}$ with $125 \mu \mathrm{g} / \mathrm{mL}$ of CAIE, CABE, CAPE, or TX-100 before staining with propidium iodide (PI). Fluorescence was quantified through flow cytometry. Data presented are mean percent PI positive cells \pm standard deviation (SD) $(n=3)$. Asterisks represent a significant difference between control cells and cells exposed to TX-100 (positive control $(p<0.05)$.

We hypothesized that the caffeic acid derivatives lead to increased oxidation within the cell. The catechol functional group found in this class of molecules can rapidly undergo a variety of redox processes to form semiquinone radicals and ortho-benzoquinones, both of which can undergo subsequent oxidative processes that can damage and/or destroy DNA and protein structures [40]. In many cases, catechols damage biomolecules through the generation of reactive oxygen species (ROS) such as superoxide $\left(\mathrm{O}_{2}{ }^{-}\right)$, hydrogen peroxide $\left(\mathrm{H}_{2} \mathrm{O}_{2}\right)$, and hydroxyl radicals $(\mathrm{OH})$ [41]. To test this hypothesis, P. larvae cells were incubated in $\mathrm{H}_{2}$ DCFDA, which is a general oxidative stress indicator that is non-fluorescent within cells $\left(\mathrm{H}_{2}\right.$ DCFDA) and becomes a highly fluorescent molecule $\left(2^{\prime}, 7^{\prime}\right.$-dichlorofluorescein (DCF)) upon cleavage of the acetate groups by intracellular esterases and oxidation. Incubation of P. larvae with CAIE, CABE, or CAPE above or at the MIC $(500,250$, and $125 \mu \mathrm{g} / \mathrm{mL}$ ) produced a significant increase in fluorescence in a dose response manner, indicating 
an increase in oxidative stress within cells at all concentrations used (Figure 2). Interestingly, the highest concentrations of CAIE, CABE, or CAPE at $500 \mu \mathrm{g} / \mathrm{mL}$ increased the intracellular fluorescence to a similar degree as $3 \% \mathrm{H}_{2} \mathrm{O}_{2}$, which is a well-known oxidant and the positive control.

To identify whether increased ROS production resulted in a significant change in antioxidant levels, intracellular glutathione (GSH) levels were quantified in P. larvae cells during three acute time points (1.5, 3 and $6 \mathrm{~h}$ ) (Figure 3). GSH levels remained consistent in vehicle treated control cells at all time points indicating the addition of the vehicle (DMSO) had no effect on intercellular GSH levels. However, brief exposure of CAPE and CAIE significantly increased GSH levels in cells by more than 2-fold $(0.25 \mu \mathrm{M}$ to $>0.69 \mu \mathrm{M})$ in less than $2 \mathrm{~h}$. GSH levels in PL cells changed most significantly when exposed to CAPE over the 6-h period. After $1.5 \mathrm{~h}$, CAPE generated the highest intracellular GSH levels $(0.93 \mu \mathrm{M})$, however, after $6 \mathrm{~h}$ CAPE decreased GSH levels to the lowest concentration quantified $(0.18 \mu \mathrm{M})$, indicating that the overproduction of ROS may lead to a subsequent decrease in antioxidant levels. Together these data support the hypothesis that caffeic acid derivatives significantly alter antioxidants levels early during exposure, and act as oxidants within cells at later time points to inhibit binary fission.

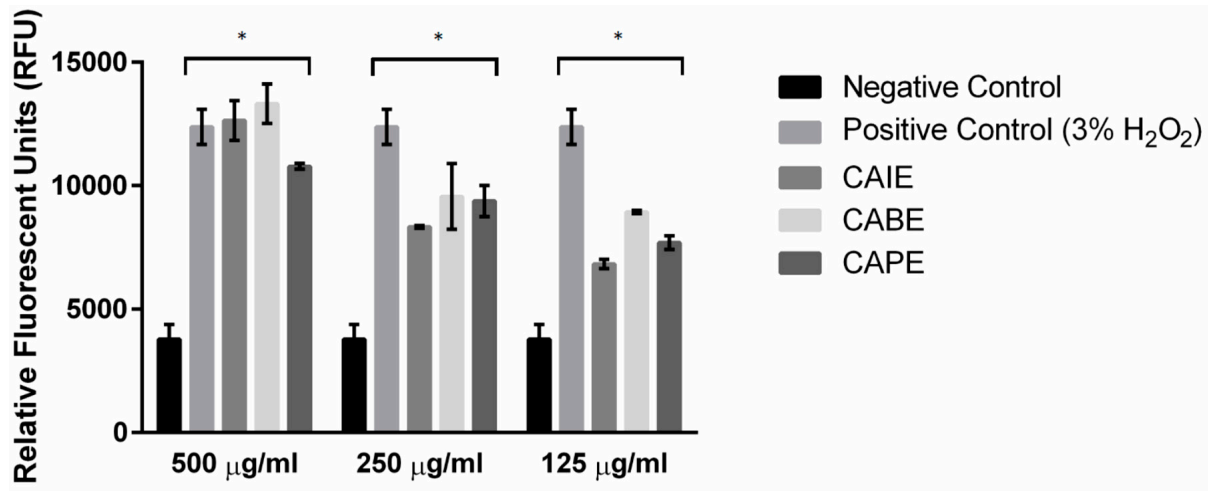

Figure 2. Quantification of intracellular reactive oxygen species in the presence of three inhibitory compounds. Paenibacillus larvae were stained with $10 \mu \mathrm{M} 2^{\prime}, 7^{\prime}$-dichlorodihydrofluorescein diacetate $\left(\mathrm{H}_{2}\right.$ DCFDA) before incubating the cells in the presence of minimum inhibitory concentrations of CAIE, $\mathrm{CAPE}, \mathrm{CABE}$ and $3 \% \mathrm{H}_{2} \mathrm{O}_{2}$ (positive control) for $18 \mathrm{~h}$ incubation at $37^{\circ} \mathrm{C}$. Fluorescence was quantified using a microplate reader at $495 \mathrm{~nm} / 527 \mathrm{~nm}(\mathrm{Ex} / \mathrm{Em})$. Data presented are mean RFU $\pm \mathrm{SD}(n=2-6)$. Asterisks represent a significant difference between control cells and cells exposed to either CAIE, CAPE, $\mathrm{CABE}$ and $3 \% \mathrm{H}_{2} \mathrm{O}_{2}(p<0.05)$.

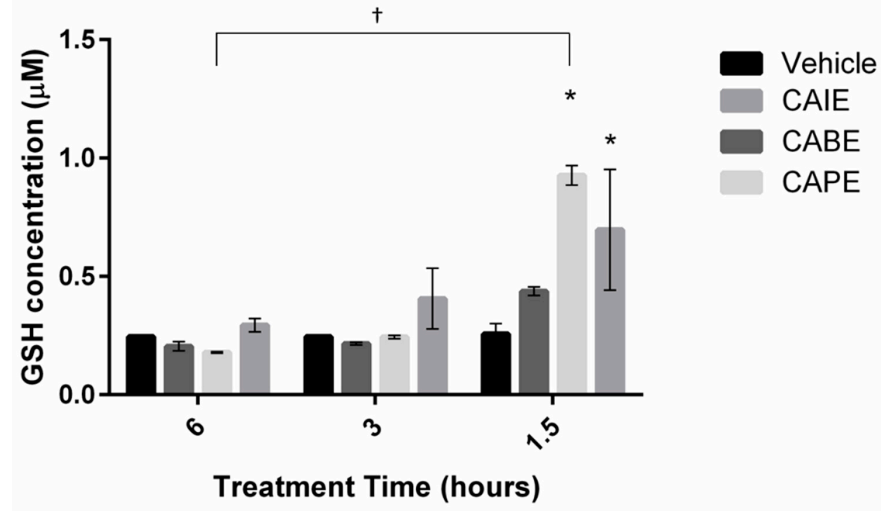

Figure 3. Quantification of intracellular glutathione (GSH) levels in the presence of three inhibitory compounds. Paenibacillus larvae were incubated in the presence of minimum inhibitory concentrations of CAIE, CAPE, CABE for up to $6 \mathrm{~h}$ at $37^{\circ} \mathrm{C}$. GSH levels was quantified by luminescence using a standard curve. Data presented are mean GSH $(\mu \mathrm{M}) \pm \mathrm{SD}(n=3)$. Asterisks represent a significant difference between control cells and cells exposed to either CAIE or CAPE $(p<0.05)$. A dagger represents a significant difference over time in Paenibacillus larvae cells exposed to CAPE. 


\section{Discussion}

As a substance, propolis represents a vast wealth of botanically derived, biologically active, natural products [22]. Despite this, isolating and testing significant quantities of any one component from a propolis matrix is problematic, as purification procedures are complex, and molecules are often found in very low concentrations [29]. Therefore, synthetically generating these natural products on a large-scale is a viable alternative for the testing and development of propolis-based therapies. To this end, we developed a rapid, three-step protocol to prepare the caffeic esters of interest. While methods for a one-step, direct esterification of the caffeic acid parent molecule exist [42], we found that our target molecules were obtained in unsatisfactory yields due to the formation of side products. To prevent these cross-esterification byproducts, we first protected the catechol alcohol functional groups [37]. After esterification of the free acid and subsequent purification, we could deprotect the catechol moiety in good yields over three steps. Conceivably, this procedure could be applied to a wide variety of structurally diverse caffeic acid esters.

Numerous studies have identified the efficacy and quantified the MICs of different naturally and synthetically derived propolis compounds against Gram-positive, Gram negative bacteria, as well as P. larvae [32,43-46]. Cinnamic acids, such as caffeic acid and ferulic acid, have been studied for their antimicrobial activities and typically show weak growth inhibition against Gram-negative bacteria compared to Gram-positive bacteria [31]. Some phenolic butyl and methyl esters have limited efficacy and inhibit bacterial growth at significantly higher concentrations $(1 \mathrm{mg} / \mathrm{mL})$ than the MICs reported in this study [43]. The inhibitory effects of these esters are improved by increasing the length of the alkyl chain to make them structurally similar to the most effective compounds identified in this study (CAPE, CAIE, and CABE). Other studies have identified the increased effectiveness of caffeic acid esters (MIC $<1.25 \mathrm{mM}$ ) against bacterial growth compared to simple phenolic esters (MIC $>5-10 \mathrm{mM}$ ) [46]. CAPE, derived from propolis from Mexico, was previously shown to be effective against Gram-positive bacteria, specifically S. aureus, at concentrations between 100 and $400 \mu \mathrm{M}$, which correlates well to the MIC of CAPE against $P$. larvae reported here $(440 \mu \mathrm{M})$. Interestingly, the combination of CAPE, CAIE, and CABE was a more potent inhibitor of bacterial growth (MIC $=\sim 90 \mu \mathrm{M}$ ) than individual compounds alone indicating an additive interaction of these compounds [32].

Recently, studies looking to identify bioactive constituents of propolis samples from Bulgaria have also identified the caffeic and ferulic ester family of molecules to be candidate therapies against $P$. larvae [33]. Through a series of chemical isolations and subsequent bioassays the researchers identified an inseparable mixture of caffeate esters that were particularly efficacious against the pathogen (lowest MIC reported for caffeate mixture by Bilikova et al. was $31.25 \mu \mathrm{M}$ after $12 \mathrm{~h}$ only). The mixture was tentatively identified as CAPE, CAIE, CABE, and isopentyl caffeic ester. Although in this study the precise concentrations of each component within the mixture was not reported, nor were individual components isolated/tested, this MIC value correlates extremely well with the value determined from the mixture of CAPE, CAIE, and CABE reported here (MIC $=31.25 \mu \mathrm{M})$.

Interestingly, in our study, CACE, while structurally similar to CAPE, CAIE, and CABE, proved to be considerably less effective (MIC $>500 \mu \mathrm{M}$ ). Correspondingly, CACE was not identified as an active component in the abovementioned fractionated bioassay study [33]. This indicates that subtle structural differences may play a significant role in the activity of this family of compounds against P. larvae.

Although many studies have identified the inhibitory effects of phenolic esters and acids, few studies have been successful at identifying a potential mechanism of action for these antimicrobials [31]. Two main mechanisms of action have been characterized for caffeic acid esters including disruption of membrane permeability and alteration of redox potentials in cells. For example, a previous study showed that 4-hydroxycinnamic acid, a cinnamic acid derivative, disrupted the outer membrane of the Gram-negative bacteria increasing the permeabilization causing cytoplasmic leakage [31]. CAPE was also shown to inhibit the growth of Gram-positive bacteria, such as Bacillus, by disrupting membrane permeability through both a bacteriostatic and bacteriocidic effect depending on the duration of 
treatment [32]. However, certain caffeic alkyl esters induce a different mechanism of action through altering the oxidant/antioxidant balance within cells leading to cell death and decreased viability [46]. Specifically, CAPE has been shown to alter oxidative processes and induce apoptosis in human cells. CAPE therefore may act through a redox mechanism as a pro-oxidant since apoptosis induced by CAPE was significantly reduced with $N$-acetyl-L-cysteine in human cells [47].

Our data support the hypothesis that CAPE, CABE, and CAIE all inhibit PL growth and kill PL cells without leading to cell lysis when used at their MIC for $18 \mathrm{~h}$ (Table 1 and Figure 1). The untreated PL cells reached stationary phase after $18 \mathrm{~h}$ of growth, as indicated by less than $10 \%$ of cells, which were PI positive. In contrast, in the presence of a low concentration of detergent (TX-100 at 0.001\%) PL cells had a small but significant increase in the number of permeabilized (or lysed) cells, which could be accurately quantified. We hypothesize the low number of permeabilized PL cells observed incubated with CAPE, CABE and CAIE is due to an inhibition and killing of PL cells that resulted in fewer total cells in culture and even fewer cells that have disrupted cell walls. Interestingly, a previous study suggested that CAPE leads to bacterial cell lysis or a bacteriocidic effect, after incubation times of greater than $6 \mathrm{~h}$, and these effects are not the same during acute incubation times where a bacteriostatic mechanism occurs. This inconsistency may be due to the different concentrations and bacteria used between studies [32]. However, CAPE can have differential effects within cells that may influence the cellular phenotypes observed. For example, CAPE can act as an antioxidant in cells, but also possesses oxidant activity [31]. Our data support this dichotomous hypothesis because the most effective caffeic acid esters induced changes in oxidant levels in bacterial cells as determined by the significant formation of ROS after $18 \mathrm{~h}$, and significant changes in antioxidant intracellular GSH levels during acute $(<6 \mathrm{~h})$ time periods which was unexpected. Increased ROS production can lead to oxidative DNA damage most likely due to the production of free radicals, such as superoxide or the hydroxyl radical, which can directly oxidize DNA into lesions like 8-hydroxy-2'-deoxyguanosine (8-oxo-2dG) [48] interfering with DNA replication, which more likely leads to a bacteriostatic effect than a bacteriocidic effect [49]. Alternatively, Gram-positive bacteria, such as B. subtilis, can alter expression levels of glutathione associated genes in response to oxidative stress [50] or induce the expression of regulons such as OxyR and SoxRS [51].

\section{Conclusions}

In conclusion, we have been able to synthetically prepare and test a series of caffeic/ferulic acids and esters against PL. We have shown that a subset of our compound library, CAPE, CAIE, and CABE inhibit the growth of PL and act as bactericidal compounds. Further experimentation indicates that these compounds alter the oxidant and antioxidant balance in cells through ROS generation and acute GSH fluctuations. We were also able to show that small structural changes within the compound library can have large effects on MIC. These results are significant because CAPE, CAIE, and CABE represent a small group of naturally occurring compounds that could be used in the future to treat antibiotic resistant PL strains. Ultimately, further screening of this family of molecules may lead to significant improvements in antimicrobial efficacy and the potential for the development of novel therapies for the prevention of AFB.

Author Contributions: Conceptualization, W.C. and D.J.B.; methodology, W.C. and D.J.B.; validation, W.C. and D.J.B.; formal analysis, W.C., N.L. and D.J.B.; investigation, W.C., N.L. and D.J.B.; data curation, W.C., N.L. and D.J.B.; writing W.C. and D.J.B.; funding acquisition, W.C., N.L. and D.J.B.

Funding: This research was funded by the Faculty Development Grant for Traditional Scholarship and Research (TS/R) at Fort Lewis College (W.C.), and from the Society of Toxicology (SOT) for undergraduate research (N.L. and D.J.B.) is gratefully acknowledged.

Acknowledgments: We also acknowledge the contribution of Peyton Valko and Jamie Curtis in generating data using purified propolis samples against $P$. larvae.

Conflicts of Interest: The authors declare no conflict of interest. 


\section{References}

1. Bruckner, S.; Steinhauer, N.; Rennich, K.; Aurell, D.; Caron, D.; Ellis, J.; Marie Fauvel, A.; Kulhanek, K.; Nelson, K.; Rangel, J.; et al. Honey Bee Colony Losses 2017-2018: Preliminary Results. Available online: https://beeinformed.org/results/honey-bee-colony-losses-2017--2018-preliminary-results/ (accessed on 15 February 2019).

2. Goulson, D.; Nicholls, E.; Botias, C.; Ratheray, E.L. Bee declines driven by combined stress from parasites, pesticides, and lack of flowers. Science 2015, 347, 1255957. [CrossRef] [PubMed]

3. Steinhauer, N.; Kulhanek, K.; Antunez, K.; Human, H.; Chantawannakul, P.; Chauzat, M.; van Engelsdorp, D. Drivers of colony losses. Curr. Opin. Insect Sci. 2018, 26, 142-148. [CrossRef] [PubMed]

4. Nazzi, F.; Brown, S.; Annoscia, D.; Del Piccolo, F.; Varricchio, P. Synergistic parasite-pathogen interactions mediated by host immunity can drive the collapse of honeybee colonies. PLoS Pathogen. 2012, 8, e1002735. [CrossRef] [PubMed]

5. Genersch, E. American foulbrood in honeybees and its caustitive agent, Paenibacillus larvae. J. Invert. Pathol. 2010, 103, 10-19. [CrossRef] [PubMed]

6. Djukic, M.; Brzuszkiewicz, E.; Funfhaus, A.; Voss, J.; Gollnow, K.; Poppinga, L.; Liesegang, H.; Garcia-Gonzales, E.; Genersch, E.; Daniel, R. How to kill the honey bee larva: Genomic potential and virulence mechanisms of Paenibacillus larvae. PLoS ONE 2014, 3, e90914. [CrossRef] [PubMed]

7. Hansen, H.; Brodsgaard, C. American foulbrood: A review of its biology, diagnosis and control. Bee World 1999, 80, 5-23. [CrossRef]

8. Ansari, M.; Al-Ghamdi, A.; Nuru, A.; Ahmed, A.; Ayaad, T.; Khan, K.; Al-Waili, N. Diagnosis and molecular detection of Paenibacilus larvae, the causative agent of American foulbrood in honeybees in Saudi Arabia. Int. J. Trop. Insect Sci. 2017, 37, 137-148. [CrossRef]

9. Cornman, R.; Lopez, D.; Evans, J. Transcriptional response of honey bee larvae infected with the bacterial pathogen Paenibacillus larvae. PLoS ONE 2013, 8, e65424. [CrossRef]

10. Powell, J.; Martinson, V.; Urban-Mead, K.; Moran, N. Routes of acquisition of the gut microbiota of the honey bee Apis melifera. Appl. Environ. Microbiol. 2014, 80, 7378-7387. [CrossRef]

11. De Graaf, D.; Alippa, A.; Brown, M.; Evans, J.; Feldlaufer, M. Diagnosis of American foulbrood in honey bees: A synthesis and proposed analytical protocols. Lett. Appl. Microbiol. 2006, 43, 583-590. [CrossRef]

12. Kochansky, J.; Knox, D.; Feldlaufer, M.; Pettis, J. Screening alternative antibiotics against oxytetracycline susceptible and resistant Paenibacillus larvae. Apidologie 2001, 32, 215-222. [CrossRef]

13. Mutinelli, F. European legislation governing the authorization of veterinary medicinal products with particular reference to the use of drugs for the control of honey bee diseases. Apiacta 2003, 38, 156-168. [CrossRef]

14. Sanford, M. Antibiotics and the Beekeeper-The FDA's Veterinarian Feed Directive (VFD). American Bee Journal. Available online: https://americanbeejournal.com/antibiotics-and-the-beekeeper, (accessed on 15 February 2019).

15. Simone-Finstrom, M.; Spivak, M. Increased resin collection after parasite challenge: A case of self-medication in honey bees? PLoS ONE 2012, 7, e34061. [CrossRef] [PubMed]

16. Simone-Finstrom, M. Social immunity and the superorganism: Behavioral defenses protecting honey bee colonies from pathogens and parasites. Bee World 2017, 94, 21-29. [CrossRef]

17. Evans, J.; Spivak, M. Socialized medicine: Individual and communal disease barriers in honey bees. J. Invert. Path. 2010, 103, S62-S72. [CrossRef]

18. Schmid-Hempel, P. Parasites in Social Insects; Princeton University Press: Princeton, NJ, USA, 1998.

19. Simone, M.; Evans, J.; Spivak, M. Resin collection and social immunity in honey bees. Evolution 2009, 63, 2016-3022. [CrossRef] [PubMed]

20. Simone-Finstrom, M.; Spivak, M. Propolis and bee health: The natural history and significance of resin use by honey bees. Apidologie 2010, 41, 295-311. [CrossRef]

21. Visscher, P. Adaptations of honey bees (Apis millifera) to problems of nest hygiene. Sociobiology 1980, 5, 249-260.

22. Lagenheim, J. Plant. Resins: Chemistry, Evolution, Ecology, and Ethanobotany; Timber Press: Portland, OR, USA, 2003. 
23. Burdock, G. Review of the biological properties and toxicity of bee propolis (propolis). Food Chem. Toxicol. 1998, 36, 347-363. [CrossRef]

24. Macucci, M. Propolis: Chemical composition, biological properties and therapeutic activity. Apidologie 1995, 26, 83-99. [CrossRef]

25. Alonso-Salces, R.; Cugnata, N.; Guaspari, E.; Pellegrini, M.; Aubone, I.; Antunez, K.; Fuselli, S. Natural strategies for the control of Paenibacillus larvae, the causative agent of American foulbrood in honey bees: A review. Apidologie 2017, 48, 387-400. [CrossRef]

26. Wilson, M.; Brinkman, D.; Spivak, M.; Gardner, G.; Cohen, J. Regional variation in composition and antimicrobial activity of US propolis against Paenibacillus larvae and Ascophaera apis. J. Invert. Path. 2015, 124, 44-50. [CrossRef] [PubMed]

27. Bastos, E.; Simone, M.; Macedo Jorge, D.; Egea Soares, A.; Spivak, M. In vitro study of the antimicrobial activity of Brazilian propolis against Paenibacillus larvae. J. Invert. Path. 2008, 97, 273-281. [CrossRef] [PubMed]

28. Siedel, V.; Peyfoon, E.; Watson, D.; Fernley, J. Comparative study of the antibacterial activity of propolis from different geographical and climatic zones. Phytotherapy Res. 2008, 22, 1256-1263. [CrossRef] [PubMed]

29. Sforcin, J.; Bankova, V. Propolis: Is there a potential for the development of new drugs? J. Ethanopharm. 2011, 133, 253-260. [CrossRef] [PubMed]

30. Woisky, R.; Salatino, A. Analysis of propolis: Some parameters and procedures for chemical quality control. J. Apic. Res. 1998, 37, 99-105. [CrossRef]

31. Guzman, J. Natural cinnamic acids, synthetic derivatives and hybrids with antimicrobial activity. Molecules 2014, 19, 19292-19349. [CrossRef]

32. Meyuhas, S.; Assali, M.; Huleihil, M. Antimicrobial activities of caffeic acid phenethyl ester. J. Molec. Biochem. 2015, 4, 21-31.

33. Bilikova, K.; Papova, M.; Trusheva, B.; Bankova, V. New anti-Paenibacillus larvae substances purified from propolis. Apidologie 2013, 44, 278-285. [CrossRef]

34. Alippi, A. American Foulbrood of Honey Bees (Infection of Honey Bees with Paenibacillus larvae). Manual of Diagnostic Tests and Vaccines for Terrestrial Animals; World Organisation for Animal Health: Paris, France, 2016; pp. 1-17.

35. Malmberg, C. Evaluation of flow Cytometry as Replacement for Plating in in vitro Measurements of Competitive Growth under Antibiotic Stress; Department of Infectious Diseases. Uppsala University: Uppsala, Sweden, 2010.

36. Van Acker, H.; Gielis, M.; Acke, F.; Cools, P.; Cos, T. The role of reactive oxygen species in antibioitic-induced cell death in Burkholderia cepacia complex bacteria. PLoS ONE 2016, 11, e0159837. [CrossRef]

37. LeBlanc, L.; Pare, A.; Jean-Francois, J.; Hebert, M.; Surette, M.; Touaibia, M. Synthesis and antiradical/antioxidant activities of caffeic acid phenethyl ester and its related propionic, acetic and benzoic acid analogues. Molecules 2012, 17, 14637-14650. [CrossRef] [PubMed]

38. Bankova, V.; Trusheva, B.; Popova, M. Caffeic Acid Phenethyl Ester (CAPE)-NATURAL Sources, Analytical Procedures and Synthetic Approaches; Comptes rendus de l'Académie bulgare des sciences; Sciences mathématiques et naturelles: Sofia, Bulgaria, 2018; Volume 71, pp. 1157-1169.

39. Jayaprakasam, B.; Vanisree, M.; Zhang, Y.; Dewitt, D.; Nair, M. Impact of alkyl esters of caffeic and ferulic acids on tumor cell proliferation, cyclooxygenase enzyme, and lipid peroxidation. J. Agric. Food Chem. 2006, 54, 5375-5381. [CrossRef]

40. Schweigert, N.; Zehnder, A.; Eggen, R. Chemical properties of catechols and their molecular modes of toxic action in cells, from microorganisms to mammals. Environ Microbiol. 2001, 3, 81-91. [CrossRef]

41. Schweigert, N.; Acero, J.; von Gunten, U.; Canonica, S.; Zehnder, A.; Eggen, R. DNA degradation by the mixture of copper and catechol is caused by DNA-copper oxo complexes, probably DNA-Cu (I) OOH. Environ. Mol. Mutagen. 2000, 36, 5-12. [CrossRef]

42. Zhang, P.; Tang, Y.; Li, N.; Zhu, Y.; Duan, J. Bioactivity and chemical synthesis of caffeic acid phenethyl ester and its derivatives. Molecules 2014, 19, 16458-16476. [CrossRef]

43. Banskota, A.; Tezuka, Y.; Kadota, S. Recent progress in pharmacological research of propolis. Phytother. Res. 2001, 15, 561-571. [CrossRef] [PubMed]

44. Cueva, C.; Moreno-Arribas, M.; Martin-Alvarez, P.; Bills, G.; Vicente, M.; Basilio, A.; Rivas, C.; Requena, T.; Rodriguez, J.; Bartolome, B. Antimicrobial activity of phenolic acids against commensal, probiotic and pathogenic bacteria. Res. Microbiol. 2010, 161, 372-382. [CrossRef] 
45. Flesar, J.; Havlik, J.; Kloucek, P.; Rada, V.; Titera, D.; Bednarm, M.; Stropnicky Mand Kokoska, L. In vitro growth-inhibitory effect of plant-derived extracts and compounds against Paenibacillus larvae and their acute oral toxicity to adult honey bees. Vet. Microbiol. 2010, 145, 129-133. [CrossRef]

46. Merkl, R.; Hradkova, L.; Filip, V.; Smidrkal, J. Antimicrobial and antioxidant properties of phenolic acids alkyl esters. Czech J. Food Sci. 2010, 28, 275-279. [CrossRef]

47. Chiao, C.; Carothers, A.; Grunberger, D.; Solomon, G.; Preston, G.; Barrett, J. Apoptosis and altered redox state induced by caffeic acid phenethyl ester (CAPE) in transformed rat fibroblast cells. Cancer Res. 1995, 55, 3576-3583.

48. Blake, D.J.; Bolin, C.M.; Cox, D.P.; Cardozo-Palaez, F.; Pfau, J.C. Internalization of Libby amphibole asbestos and induction of oxidative stress in murine macrophages. Toxicol. Sci. 2007, 99, 277-288. [CrossRef] [PubMed]

49. Imlay, J. Diagnosing oxidative stress in bacteria: Not as easy as you might think. Curr. Opin. Microbiol. 2015, 24, 124-131. [CrossRef] [PubMed]

50. Zhang, Y.; Meng, D.; Wang, Z.; Guo, H.; Wang, Y. Oxidative stress response in two representative bacteria exposed to atrazine. FEMS Microbiol. Lett. 2012, 334, 95-101. [CrossRef] [PubMed]

51. Cabiscol, E.; Tamarit, J.; Ros, J. Oxidative stress in bacteria and protein damage by reactive oxygen species. Int. Microbiol. 2000, 3, 3-8. [PubMed]

(C) 2019 by the authors. Licensee MDPI, Basel, Switzerland. This article is an open access article distributed under the terms and conditions of the Creative Commons Attribution (CC BY) license (http://creativecommons.org/licenses/by/4.0/). 